\begin{tabular}{cc|c}
\hline Tar. Bil. Der. & Tarm Bilimleri Dergisi & Journal of Agricultural Sciences \\
& $\begin{array}{c}\text { Dergi web sayfası: } \\
\text { www.agri.ankara.edu.tr/dergi }\end{array}$ & Journal homepage: \\
& www.agri.ankara.edu.tr/journal
\end{tabular}

\title{
The Impact of Soil Conditioners on Some Chemical Properties of Soil and Grain Yield of Corn (Zea Mays L.)
}

\author{
Melis ÇERÇİĞGLU \\ ${ }^{a}$ Department of Laboratory Technology, Vocational College of Simav, Kutahya Dumlupinar University, Simav, Kutahya, 43500, TURKEY
}

\section{ARTICLE INFO}

Research Article

DOI: 10.15832/ankutbd.399164

Corresponding Author: Melis ÇERÇİOĞLU, E-mail: melis.cercioglu@dpu.edu.tr, Tel: +90 (274) 44343 43/6525

Received: 27 February 2018, Received in Revised Form: 04 April 2018, Accepted: 17 April 2018

\begin{abstract}
The goal of this study was to explore the effects of various soil conditioners on selected properties ( $\mathrm{pH}$; organic matter, OM; electrical conductivity, EC; cation exchange capacity, CEC) of a Xerofluvent soil and corn yield. During the experiment, four amendments were applied in an experimental set of plots: tobacco waste compost (TWC), poultry manure (PM), bio-humus (BH), and chemical fertilizer (NPK). Soils were treated with TWC at the rate $50 \mathrm{t} \mathrm{ha} \mathrm{C}^{-1}, \mathrm{PM}^{\mathrm{N}}$ at the rate $4 \mathrm{tha}^{-1}, \mathrm{BH}$ at the rate $10 \mathrm{tha}^{-1}$ and NPK at the rate $300 \mathrm{~kg} \mathrm{ha}^{-1}$, respectively. All organic conditioners were increased soil $\mathrm{pH}, \mathrm{OM}, \mathrm{CEC}, \mathrm{EC}$ and corn yield when compared with the control soil and these parameters have been changed from $5.7 \%$ to $333 \%$. The most effective soil conditioners were determined as tobacco waste compost, biohumus, and poultry manure. The findings of current study suggest that $50 \mathrm{tha}^{-1} \mathrm{TWC}$ should be added to soil as a priority for improving properties of a Typic Xerofluvent soil and crop yield.
\end{abstract}

Keywords: Bio-humus; Poultry manure; Soil chemical properties; Tobacco waste; Yield

\section{Introduction}

Nowadays, the use of organic treatments for soil nutrient improvement is getting important for sustainable productivity and soil nutrient management. The decline of organic matter in soil, as a consequence of intensive soil cultivation practices, has been identified as one of the most important threats to soil quality (Lal 2007; Batlle-Bayer et al 2010). Use of organic manures alongside chemical fertilizers often lead to increased soil organic matter, soil structure, water holding capacity and improved nutrient cycling and helps to maintain soil nutrient composition, cation exchange capacity and biological activities (Saha et al 2008). While chemical fertilizers are important input to enhance crop productivity, over reliance on chemical fertilizers is associated with decline in some soil properties and crop yields over time (Hepperly et al 2009). Hence, integrated use of chemical fertilizers with organic manures is a sustainable approach for efficient nutrient usage which enhances efficiency of the chemical fertilizers while reducing nutrient losses (Schoebitz \& Vidal 2016). Compost amendments could contribute significantly to the improvement of the soil organic carbon content in the long term (Barral et al 2009) and hence to the chemical (nutrients), 
physical (structure and moisture retention) and biological (soil life) quality of the soil (Herencia et al 2011; Odlare et al 2011; Ozores-Hampton et al 2011). Plant residuals can be used as a nutrient supplement in the agricultural fields. The kinetics of plant residual decomposition in soil and their carbon and nitrogen mineralization are largely influenced by the quality of the plant materials, i.e. by their origin and composition (Heal et al 1997). Animal manures may contribute to improving the physical and biological properties of soil ( $\mathrm{Li} \&$ Han 2016) and are important source of $\mathrm{Ca}, \mathrm{Mg}$, $\mathrm{S}$, and micronutrients; they contain only low and highly amounts of N, P, and K (Odedina et al 2011). Among the different sources of organic manure which have been used in plant production, poultry manure is found to be the most concentrated in terms of nutritional status (Obire \& Akinde 2006). The efficiency of compost usage in agriculture mostly depends on the quality of the compost which is closely related to its stability and maturity. Some physico-chemical properties $(\mathrm{pH}$, temperature, $\mathrm{C}: \mathrm{N}$ ratio, cation exchange capacity, total organic $\mathrm{C}$, $\mathrm{NH}_{4}^{+}$, phenols, humic-like substances) have been used to control compost quality. Nevertheless, it is difficult to add these parameters across a wide range of composts prepared from different organic wastes (Kayıkçığlu \& Okur 2011). Tobacco is an important agricultural plant in the Aegean region of Turkey and $60.5 \%$ of Turkey's total tobacco production is grown in this region according to 2016 data (TUIK 2017). Tobacco plant residues from the primary production and cigarette manufacture are classified as an agro-industrial waste. This waste contains high amounts of organic matter and nicotine and is known to be a toxic and hazardous compound if the nicotine content exceeds $500 \mathrm{mg}$ $\mathrm{kg}^{-1}$ dry weight (Wang et al 2004; PiotrowskaCyplik et al 2009). In this investigation, tobacco waste compost (TWC), poultry manure (PM), bio-humus (BH), and chemical fertilizer (NPK) at different ratios was applied to soil and the influences of these conditioners on selected chemical properties of a sandy loam soil and corn yield were compared.

\section{Material and Methods}

\subsection{Site features and properties of conditioners}

The experiment was laid out at the Agricultural Research Farm of Ege University in Menemen, Izmir, Turkey $\left(38^{\circ} 58^{\prime} 35.51^{\prime \prime}-38^{\circ}\right.$ $\left.58^{\prime} 36.03^{\prime \prime} \mathrm{N} ; \quad 27^{\circ} 03^{\prime} 84.56^{\prime \prime}-27^{\circ} 03^{\prime} 89.81^{\prime \prime} \mathrm{E}\right) . \quad$ The aim of this study to compare the role of different materials on soil chemical properties and corn yield. The soil at the study site is characterized by sandy loam texture with slightly alkaline reaction and classified as a Typic Xerofluevent (Soil Survey Staff 2006). The general properties of the soil are shown in Table 1. Experimental treatments were as follows: (1) Control soil, C (No treatment); (2) Poultry manure, PM at $4 \mathrm{t} \mathrm{ha}^{-1}$ plus NPK fertilizer at $300 \mathrm{~kg} \mathrm{ha}^{-1}$; (3) Bio-humus, BH at $10 \mathrm{t} \mathrm{ha}^{-1}$ plus NPK fertilizer at $300 \mathrm{~kg} \mathrm{ha}^{-1}$; (4) NPK fertilizer at $300 \mathrm{~kg} \mathrm{ha}^{-1}$; (5) Tobacco waste compost, TWC at 50 t ha ${ }^{-1}$. Since tobacco waste compost had very rich organic matter and nutrient content, it was applied to the soil (at a higher dose than other materials) without NPK. Moreover, some researchers reported that tobacco waste compost had positive responses to soil properties and yield without any mineral fertilizer (Okur et al 2008; Cercioglu et al 2012). The plot sizes were $5 \mathrm{~m} \mathrm{x} 3 \mathrm{~m}$ and replicated four times according to a randomized block design. The test plant grown on the study field was corn (Zea Mays L.), planted during April-May-June and harvested in October of each growing season. The organic treatments [tobacco waste compost (TWC), poultry manure $(\mathrm{PM})$ and bio-humus $(\mathrm{BH})]$ were applied to the soil only once at the beginning of the experiment (first year). Some properties of these materials are given in Table 2 and Table 3. Tobacco wastes obtained from Izmir Kemalpaşa Socotab Factory were added to soil after composting process. Composting of tobacco waste was performed outdoor under a roof. The moisture content of the compost was analyzed approximately $55 \%$ by weighing the material regularly and adding water when necessary. Aeration was made by manual turning during the composting. After 3 months, when the temperature of the compost decreased 
to the ambient level, composting was completed. Both of bio-humus (composted plant residues) and poultry manure were gathered from organic manure industry. All rates of treatments were determined according to initial soil analysis results, uptake of nutrients by plant, and recommendations from producers of organic manure. Moreover, some additional chemical fertilizers (ammonium sulfate, triple superphosphate, and ammonium nitrate) were applied, and drip irrigation method was used in the study.

\subsection{Soil sampling and analytical determinations}

Two soil samples $(0-20 \mathrm{~cm})$ were collected (planting and harvest period) each growing season from the center of each plot. To determine the initial physical and chemical properties of the soil, soil samples were air-dried and passed through a 2-mm sieve prior to analysis. Particle-size distribution was determined according to Bouyoucos (1962) and porosity was determined according to Danielson \& Sutherland
(1986). Organic matter concentration (Nelson \& Sommers 1982), pH (Jackson 1967), electrical conductivity (Rhoades 1996) and cation exchange capacity (Rhoades 1982a) were determined. Calcium carbonate was measured by the Scheibler method (Tüzüner 1990). Total N was analyzed by the Kjeldahl method and available $\mathrm{K}, \mathrm{Ca}, \mathrm{Mg}$ and $\mathrm{Na}$ were determined by the $1 \mathrm{~N} \mathrm{NH}_{4} \mathrm{OAc}(\mathrm{pH}: 7)$ method. $\mathrm{Ca}, \mathrm{K}$ and $\mathrm{Na}$ were determined by flame emission spectrometry and $\mathrm{Mg}$ was determined by flame atomic absorption spectrometry (AAS) (Kacar 1995). Available $\mathrm{P}$ was determined by the Mo blue method in a $\mathrm{NaHCO}_{3}$ extract (Olsen \& Sommers 1982). Available Fe, $\mathrm{Cu}, \mathrm{Zn}$ and $\mathrm{Mn}$ were obtained with $40 \mathrm{~mL}$ DTPA $+\mathrm{CaCl}_{2}+$ TEA extract method and were found by atomic absorption spectrometry (Lindsay \& Norvell 1978). Grain yield measurements were performed by 10 crops from each plots and the values were calculated by measuring total weight, corncob weight, and grain weight in $\mathrm{tha}^{-1}$.

Table 1- Some soil properties for the Ege University Menemen Agricultural Research Farm study site (sandy loam)

\begin{tabular}{ccccccccc}
\hline $\begin{array}{c}\text { Depth } \\
(\mathrm{cm})\end{array}$ & $\begin{array}{c}\text { Sand } \\
(\%)\end{array}$ & $\begin{array}{c}\text { Silt } \\
(\%)\end{array}$ & $\begin{array}{c}\text { Clay } \\
(\%)\end{array}$ & $p H$ & $\begin{array}{c}E C \\
\left.(\mathrm{dS} \mathrm{m})^{-1}\right)\end{array}$ & $\begin{array}{c}\mathrm{OM} \\
(\%)\end{array}$ & $\begin{array}{c}\mathrm{CaCO}_{3} \\
(\%)\end{array}$ & $\begin{array}{c}\text { Total N } \\
(\%)\end{array}$ \\
\hline $0-30 \mathrm{~cm}$ & 55.28 & 36.00 & 8.72 & 7.78 & 0.72 & 1.11 & 4.70 & 0.07 \\
\hline
\end{tabular}

Table 2- Main chemical quality characteristics of tobacco waste compost (TWC), poultry manure (PM), and bio-humus (BH)

\begin{tabular}{lccccc}
\hline Material & $p H$ & $\begin{array}{c}E C \\
\left(d \mathrm{~S} \mathrm{~m}^{-1}\right)\end{array}$ & $\begin{array}{c}\mathrm{OM} \\
(\%)\end{array}$ & $\mathrm{C}: \mathrm{N}$ & $\begin{array}{c}\mathrm{CaCO}_{3} \\
(\%)\end{array}$ \\
\hline TWC & 9.18 & 49.50 & 33.60 & 22.40 & 7.06 \\
PM & 8.60 & 54.50 & 44.90 & 25.80 & 12.00 \\
BH & 7.88 & 9.20 & 46.50 & 29.30 & 26.00 \\
\hline
\end{tabular}

Table 3- Nutrient status of tobacco waste compost (TWC), poultry manure (PM), and bio-humus (BH)

\begin{tabular}{|c|c|c|c|c|c|c|c|c|c|c|}
\hline \multirow{2}{*}{ Material } & \multicolumn{5}{|c|}{$\%$} & \multicolumn{5}{|c|}{ ppm } \\
\hline & $N$ & $P$ & $K$ & $\mathrm{Ca}$ & $M g$ & $\mathrm{Na}$ & $\mathrm{Fe}$ & $\mathrm{Cu}$ & $M n$ & $Z n$ \\
\hline TWC & 0.87 & 0.27 & 1.94 & 7.44 & 0.63 & 794.80 & 14500.00 & 119.00 & 442.00 & 124.00 \\
\hline $\mathrm{PM}$ & 1.01 & 0.34 & 2.19 & 9.44 & 1.20 & 5663.00 & 2200.00 & 72.20 & 536.30 & 648.60 \\
\hline $\mathrm{BH}$ & 0.92 & 0.20 & 0.69 & 11.76 & 0.92 & 993.50 & 12400.00 & 34.80 & 433.80 & 86.14 \\
\hline
\end{tabular}




\subsection{Statistical analysis}

Analysis of variance (ANOVA) and Duncan's tests were performed with a $\mathrm{P} \leq 0.05$ significance level and $95 \%$ confidence interval using the statistical package, SPSS Statistics 25 .

\section{Results and Discussion}

\subsection{Soil chemical properties}

Soil $\mathrm{pH}$ values were significantly affected by all the treatments and varied between 7.49 and 7.92 $(\mathrm{P} \leq 0.05$, Figure 1a). Soil under TWC treatment had significantly higher $\mathrm{pH}$ values than the other treatments. The highest $\mathrm{pH}$ (7.92) was observed with an increase of $3.6 \%$ over the control in the first growing season. There were no significant differences between the PM and $\mathrm{BH}$ treatments in the first and third growing season $(\mathrm{P} \leq 0.05)$. The study conducted by Mabuhay et al (2006) agreed with these results; they found that soil $\mathrm{pH}$ increased when organic and chemical fertilizers were applied to agricultural lands. Nastri et al (2009) observed very slight soil $\mathrm{pH}$ response to addition of either organic or inorganic fertilizers. Giannakis et al (2014) reported that compost application increased soil $\mathrm{pH}$ from 7.80 to 8.10 and 8.20 in the 50 and $100 \mathrm{t} \mathrm{ha}^{-1}$ application rates, respectively, at the 0-15 $\mathrm{cm}$ soil layer. Soil electrical conductivity (EC) was significantly different among all the treatments and varied between 0.45 and $1.95 \mathrm{dS} \mathrm{m}^{-1}(\mathrm{P} \leq 0.05$, Figure 1b). PM and TWC treatments showed same significant effect on soil EC values in the second growing season; TWC and NPK treatments also showed same significant effect in the third growing season $(\mathrm{P} \leq 0.05)$. Release or solubilization of ions during compost incorporation may have resulted in the increased values of EC observed at the beginning of the study. Applying composted tobacco waste and poultry manure to soil raised the EC due to high level EC values of these materials (TWC: $49.50 \mathrm{dSm}^{-1}$; PM: $\left.54.50 \mathrm{dSm}^{-1}\right)$. Several researchers reported that addition of organic manure and compost to the soils significantly increased electrical conductivity (Candemir \& Gulser 2011; Morugan-Coronado et al 2011; Cercioglu et al 2012). Addition of TWC, BH and PM were increased significantly soil organic matter $(\mathrm{OM})$ at each growing season (Figure 2a). According to the results, $\mathrm{OM}$ values were significantly $(\mathrm{P} \leq 0.05)$ greater $(124 \%)$ in the TWC treatment when compared with the control treatment in 2009. Third growing season showed the greatest OM values (2.51 and $2.45 \%$ ) by the PM and TWC treatments among all the growing seasons. The soil $\mathrm{OM}$ content was increased because of high OM content of organic materials (see Table 2). The increase in the levels of soil OM was expected, since, organic sources have the ability of increasing soil OM content (Ojeniyi 2000). Cercioglu et al (2012) reported that addition of composted tobacco waste on a loamy soil also increased soil organic matter content. Nevertheless, some studies showed that $\mathrm{OM}$ increases were temporary, since the organic material is rapidly mineralized by soil microorganisms (Mechri et al 2007; Di Serio et al 2008). Cation exchange capacity (CEC) is defined as the measure of the total capacity of a soil to hold exchangeable cations and indicates the negative charge present per unit mass of soil (Peverill et al 1999). With application of all the treatments, CEC values varied between 114.1 and $196.6 \mathrm{cmol}(+) \mathrm{kg}^{-1}$ (Figure $2 \mathrm{~b}$ ). The greatest CEC value was obtained as $196.6 \mathrm{cmol}(+) \mathrm{kg}^{-1}$ in the second growing season by increasing the rate $31 \%$ in the $\mathrm{BH}$ treatment. The TWC treatment also showed greater CEC values (124 and $145.6 \mathrm{cmol}(+) \mathrm{kg}^{-1}$ ) in the first and third growing seasons. The increase in CEC of soil, as the result of organic material addition, has been reported by several researchers (Qian et al 2004; Jien \& Wang 2013).

\subsection{Corn yield}

Grain yield values significantly varied between 6.62 and $24.36 \mathrm{t} \mathrm{ha}^{-1}$ by all the treatments $(\mathrm{P} \leq 0.05$, Figure 3). Poultry manure treatment had the greatest yield $\left(24.36 \mathrm{t} \mathrm{ha}^{-1}\right)$ value in the first harvest with an increase of $42.3 \%$ over the control. Since the second and third growing season had an extreme dryness, yield results decreased during this time of the study. The addition of PM and TWC to soils significantly increased grain yield $(\mathrm{P} \leq 0.05)$. Positive 
(a)

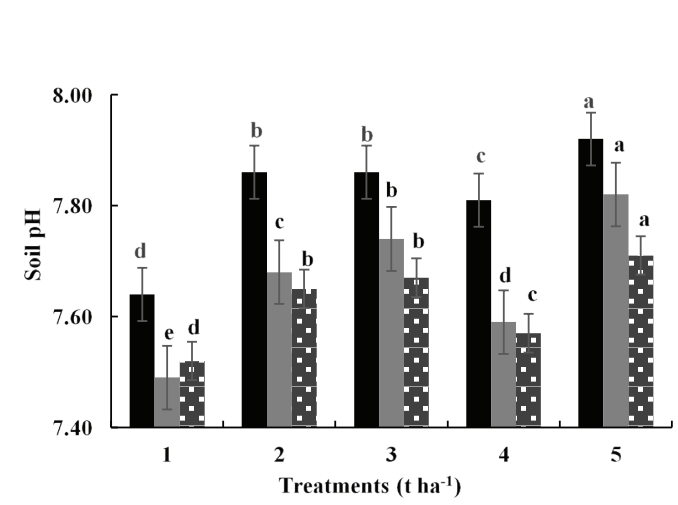

(b)

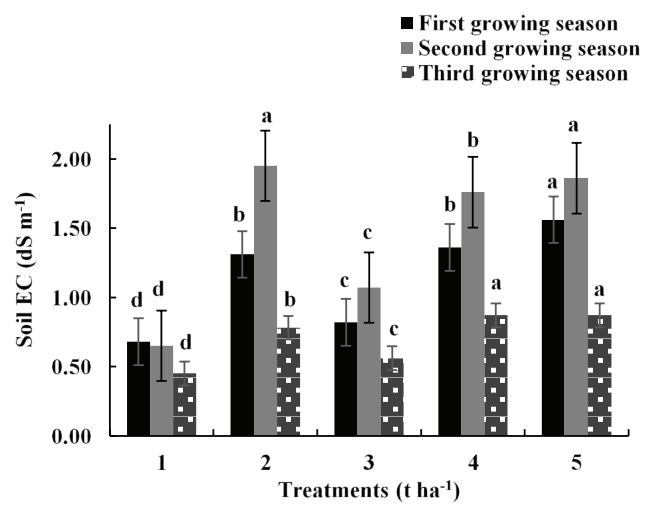

Figure 1- Changes in (a), soil pH; (b), soil EC (dS m $\left.{ }^{-1}\right)$. Treatments 1, control soil; 2, poultry manure (4 t ha $\left.\mathbf{~}^{-1}\right)$ +NPK (300 kg ha-1); 3, bio-humus $\left(10 \mathrm{t} \mathrm{ha}^{-1}\right)+$ NPK $\left(300 \mathrm{~kg} \mathrm{ha}^{-1}\right) ; 4$, NPK $\left(300 \mathrm{~kg} \mathrm{ha}^{-1}\right)$; 5, tobacco waste compost $\left(50 \mathrm{t} \mathrm{ha}^{-1}\right)$. The error bars represent the mean $\pm \mathrm{SE}$ of four replicates $(\mathrm{n}=4)$. The letters presents significance levels among treatments for each growing season according to Duncan's test $(\mathrm{P} \leq \mathbf{0 . 0 5})$

(a)

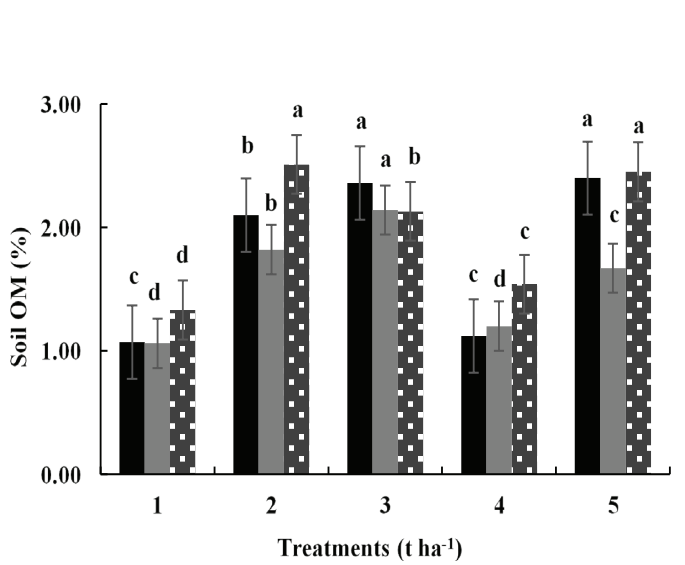

(b)

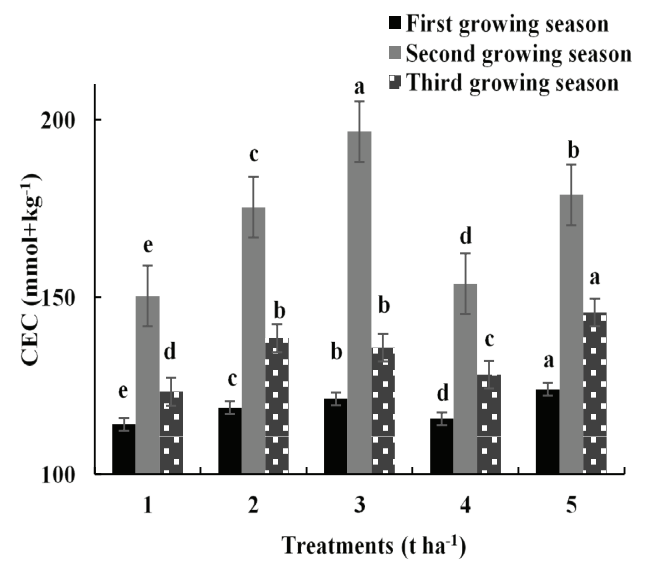

Figure 2- Changes in (a), soil OM (\%); (b), soil CEC (cmol+kg-1). Treatments 1, Control soil; 2, Poultry manure $\left(4 \mathrm{t} \mathrm{ha}^{-1}\right)+$ NPK (300 kg ha-1); 3, Bio-humus (10 t ha')+NPK (300 kg ha-1); 4, NPK (300 kg ha-1); 5, tobacco waste compost $\left(50 \mathrm{t} \mathrm{ha}^{-1}\right)$. The error bars represent the mean $\pm \mathrm{SE}$ of four replicates $(\mathrm{n}=4)$. The letters presents significance levels among treatments for each growing season according to Duncan's test $(\mathrm{P} \leq 0.05)$

yield responses in various plants to the addition of composted tobacco waste have been mentioned in several studies (Jakubus \& Czekala 2002; Cercioglu et al 2012; Cercioglu 2017). Ojeniyi \& Adeniyan (1999) reported that poultry manure can effectively improve soil fertility, yield and nutrient composition of plant. Similarly, Garg \& Bahla (2008) found that higher grain yield with increased poultry manure could be because of balanced nutrients supply throughout the growth and development stages of plant. Studies conducted by Ayoola \& Makinde (2009), obtained greater grain yield in poultry 
manure treatments and lower in chemical fertilizer and control treatments. Poultry manure and chemical fertilizer combinations can improve the efficiency of nutrients uptake and availability to plant (Warren et al 2006). Similar yield results found in the current study has also occurred in other studies.

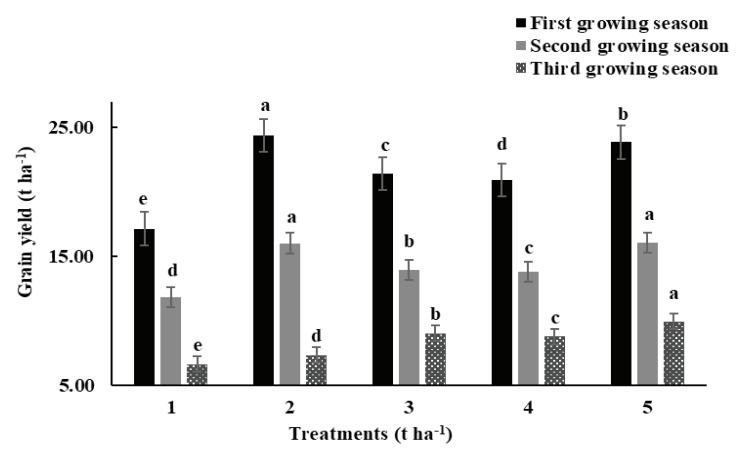

Figure 3- Changes in grain yield $\left(\mathrm{t} \mathrm{ha}^{-1}\right)$. Treatments 1, Control soil; 2, Poultry manure (4 t ha $\left.{ }^{-1}\right)+N P K(300$ kg ha-1); 3, Bio-humus (10 t ha $\left.{ }^{-1}\right)+$ NPK (300 kg ha-1); 4, NPK (300 kg ha-1); 5, tobacco waste compost (50 t $\left.h^{-1}\right)$. The error bars represent the mean $\pm \mathrm{SE}$ of four replicates $(n=4)$. The letters presents significance levels among treatments for each growing season according to Duncan's test $(\mathrm{P} \leq \mathbf{0 . 0 5})$

\section{Conclusions}

Generally, organic materials added to the soil significantly $(\mathrm{P} \leq 0.05)$ enhanced soil $\mathrm{pH}$, electrical conductivity, organic matter content, and cation exchange capacity compared to the control soil. Improvement of the soil chemical properties is important for plant yield especially for Izmir where its plant and fruit production are prominent among agricultural industries of Turkey. The benefited methods and results from this study have demonstrated that soil chemical properties are changed significantly by addition of different organic treatments. Similarly, grain yield of corn was changed by applying these amendments. However, occasionally using these materials may cause some problems. For instance, high salinity of poultry manure is the most important factor limiting the use of it. It is therefore recommended to apply to the soil after analyzing the salt content of poultry manure. Additionally, due to the fact that experiment soil has high sand content, provides permeable structure and the applications do not cause a soil pollution problem. Nevertheless, they might cause pollution of groundwater. Hence, these materials should be added to the soil (tobacco waste compost, poultry manure and bio-humus) for improving soil properties of a Typic Xerofluvent soil.

\section{Acknowledgements}

I would like to express my thanks to Ege University for their financial support of this study as a scientific research project (09-ZRF-031)

\section{References}

Ayoola O T \& Makinde E A (2009). Maize growth, yield and soil nutrient changes with $\mathrm{N}$ enriched. organic fertilizers. African Journal of Food Agricultural and Nutritional Development 9(1): 580-592

Barral M T, Paradelo R, Moldes A B, Dominguez M \& Diaz-Fierros F (2009). Utilization of MSW compost for organic matter conservation in agricultural soils of NW Spain. Resources, Conservation and Recycling 53(9): 529-534

Batlle-Bayer L, Batjes N H \& Bindraban P S (2010). Changes in organic carbon stocks upon land use conversion in the Brazilian Cerrado: A review. Agriculture, Ecosystems and Environment 137: 47-58

Bouyoucos G J (1962). Hydrometer method improved for making particle size analyses of soils. Agronomy Journal 54(5): 464-465

Candemir F \& Gulser C (2011). Effects of different agricultural wastes on some soil quality indexes in clay and loamy sand fields. Communications in Soil Science and Plant Analysis 42(1): 13-28

Cercioglu M (2017). The role of organic soil amendments on soil physical properties and yield of maize (Zea Mays L.). Communications in Soil Science and Plant Analysis 48(6): 683-691

Cercioglu M, Okur B, Delibacak S \& Ongun A R (2012). Effects of tobacco waste and farmyard manure on soil properties and yield of lettuce (Lactuca sativa L. var. capitata). Communications in Soil Science and Plant Analysis 43(6): 875-886 
Danielson R E \& Sutherland P L (1986). Porosity. In: A. Klute (Ed), Methods of Soil Analysis Part I: Physical and Mineralogical Methods, ASA-SSA $2^{\text {nd }}$ Ed., Madison, Wisconsin, pp. 443-461

Di Serio M G, Lanza B, Mucciarella M R, Russi F, Iannucci E, Marfisi P \& Madeo A (2008). Effects of olive mill wastewater spreading on the physicochemical and microbiological characteristics of soil. International Biodeterioration \& Biodegradation 62(4): 403-407

Garg S \& Bahla G S (2008). Phosphorus availability to maize as influenced by organic manures and fertilizer $\mathrm{P}$ associated phosphatase activity in soils. Bioresource Technology 99(13): 5773-5777

Giannakis G V, Kourgialas N N, Paranychianakis N V, Nikolaidis N P \& Kalogerakis N (2014). Effects of municipal solid waste compost on soil properties and vegetables growth. Compost Science \& Utilization 22(3): 116-131

Heal O W, Anderson J M \& Swift J M (1997). Plant litter quality and decomposition: a historical overview. In: G Cadisch \& K E Giller (Eds.), Driven by Nature: Plant Litter Quality and Decomposition. CAB International, Wallingford, UK, pp. 3-30

Hepperly Y P, Lotter D, Ulsh C Z, Siedel R \& Reider C (2009). Compost, manure and synthetic fertilizer influences crop yields, soil properties, nitrate leaching and crop nutrient content. Compost Science \& Utilization 17(2): 117-126

Herencia J F, Garcia-Galavis P A \& Maqueda C (2011). Long-term effect of organic and mineral fertilization on soil physical properties under greenhouse and outdoor management practices. Pedosphere 21(4): 443-453

Jackson M L (1967). Soil Chemical Analysis. PrenticeHall of India, Private Limited, New Delhi, India

Jakubus M \& Czekala J (2002). The utilization of tobacco dust as a source of nitrogen for plants and of carbon for the formation of humus compounds in the soil. In: Proceedings of the $10^{\text {th }}$ International Conference of the RAMIRAN Network, 14-18 May, HlinkovaKos ice, Slovak Republic: University of Veterinary Medicine, Research Institute of Veterinary Medicine, pp. 195-196

Jien S H \& Wang C S (2013). Effects of biochar on soil properties and erosion potential in a highly weathered soil. Catena 110: 225-233
Kacar B (1995). Bitki ve Toprağın Kimyasal Analizleri III: Toprak Analizleri. Ankara Üniversitesi Ziraat Fakültesi Eğitim Araştırma ve Gelişme Vakfı Yayınları, No: 3, $705 \mathrm{~s}$

Kayıkçığlu H H \& Okur N (2011). Evolution of enzyme activities during composting of tobacco waste. Waste Management and Research 29(11): 1124-1133

Lal R (2007). Anthropogenic influences on world soils and implications to global food security. Advances in Agronomy 93: 69-93

Li L J \& Han X Z (2016). Changes of soil properties and carbon fractions after long-term application of organic amendments in Mollisols. Catena 143: 140-144

Lindsay W L \& Norvell W A (1978). Development of a DTPA soil test for zinc, iron manganese and copper. Soil Science Society of America Journal 42(3): 421428

Mabuhay J A, Nakagoshi N \& Isagi Y (2006). Microbial responses to organic and inorganic amendments in eroded soil. Land Degradation and Development 17(3): 321-332

Mechri B, Echbili A, Issaoui M, Braham M, Elhadj S B \& Hammami M (2007). Short-term effects in soil microbial community following agronomic application of olive mill wastewaters in a field of olive trees. Applied Soil Ecology 36(2-3): 216-223

Morugan-Coronado A, Garcia-Orenes F, Mataix-Solera J, Arcenegui V \& Mataix-Beneyto J (2011). Shortterm effects of treated wastewater irrigation on Mediterranean calcareous soil. Soil \& Tillage Research 112(1): 18-26

Nastri A, Triberti L, Giordani G, Comellini F \& Baldoni G (2009). Direct and residual effects of manure on soil chemical properties. Geophysical Research Abstracts Vol. 11, EUG2009-4488-1

Nelson D W \& Sommers L E (1982). Organic matter. In: Methods of Soil Analysis Part II: Chemical and Microbiological Properties, $2^{\text {nd }}$ Edition, Agronomy, No: 9, pp. 574-579

Obire O \& Akinde S B (2006). Comparative study of the efficiency of cow dung and poultry manure as nutrient sources in bioremediation of oil polluted soil. Niger Delta Biologia 5(2): 82-91

Odedina J N, Odedina S A \& Ojeniyi S O (2011). Effect of types of manure on growth and yield of cassava (Manihot esculenta, Crantz). Researcher 3(5): 1-8 
Odlare M, Arthurson V, Pell M, Svensson K, Nehrenheim E \& Abubaker J (2011). Land application of organic waste: Effects on the soil ecosystem. Applied Energy 88(6): 2210-2218

Ojeniyi S O (2000). Effect of goat manure on soil nutrients content and okra yield in rainforest area of Nigeria. Applied Tropical Agricultural Journal 5: 20-23

Ojeniyi S O \& Adeniyan N O (1999). Effect of poultry manure and NPK fertilizer on soil fertility nutrients content and yield of maize at Akure. Southwest Nigeria. In: Proceedings of the $25^{\text {th }}$ Annual Conference of Soil Science Society of Nigeria, 21-25 November, Benin City, Nigeria, pp. 185-191

Okur N, Kayikcioglu H H, Okur B \& Delibacak S (2008). Organic amendment based on tobacco waste compost and farmyard manure: Influence of soil biological properties and butter-head lettuce yield. Turkish Journal of Agriculture and Forestry 32: 91-99

Olsen S R \& Sommers E L (1982). Phosphorous availability indices, phosporus soluble in sodium bicarbonate. In: A L Page, P H Miller \& D R Keeney (Eds), Methods of Soil Analysis, Part II: Chemical and Microbiological Properties. $2^{\text {nd }}$ Edition, American Society of Agronomy, Madison, WI, pp. 404-430

Ozores-Hampton M, Stansly P A \& Salame T P (2011). Soil chemical, physical, and biological properties of a sandy soil subjected to long-term organic amendments. Journal of Sustainable Agriculture 35(3): 243-259

Peverill K I, Sparrow L A \& Reuter D J (1999). Soil Analysis: An Interpretation Manual. CSIRO Publishing, Melborne

Piotrowska-Cyplik A, Olejnik A, Cyplik P, Dach J \& Czarnecki Z (2009). The kinetics of nicotine degradation, enzyme activities and genotoxic potential in the characterization of tobacco waste composting. Bioresource Technology 100: 5037-5044

Qian P, Schoenau J J \& Mooleki P (2004). Phosphorus amount and distribution in a Saskatchewan soil after five years of swine and cattle manure application. Canadian Journal of Soil Science 84(3): 275-281

Rhoades J D (1982a). Cation exchange capacity. In: Methods of Soil Analysis Part II: Chemical and Microbiological Properties, $2^{\text {nd }}$ Edition, Agronomy, No: 9, pp. 149-157

Rhoades J D (1996). Salinity: Electrical conductivity and dissolved soilds. In: Methods of Soil Analysis Part III: Chemical Methods, $2^{\text {nd }}$ Edition, Agronomy, No: 15, Madison, Wisconsin, pp. 417-436

Saha S, Mina B L, Gopinath K A, Kundu S \& Gupta H S (2008). Organic amendments affect biochemical properties of a subtemperate soil of the Indian Himalayas. Nutrient Cycling in Agroecosystems 80(3): 233-242

Schoebitz M \& Vidal G (2016). Microbial consortium and pig slurry to improve chemical properties of degraded soil and nutrient plant uptake. Journal of Soil Science and Plant Nutrition 16(1): 226-236

Soil Survey Staff (2006). Keys to Soil Taxonomy. $10^{\text {th }}$ Edition, U.S. Government Printing Office, Washington, D.C

TUIK (2017). Turkish Statistical Institute data basisagriculture. http://www.tuik.gov.tr (Date of access: 25.12.2017)

Tüzüner A (1990). Toprak ve Su Analiz Laboratuvarları El Kitabı. Tarım Orman ve Köy İşleri Bakanlığı Köy Hizmetleri Genel Müdürlüğü Yayın No: 279, Ankara

Wang P, Changa C M, Watson M E, Dick W A, Chen Y \& Hoitink H A J (2004). Maturity indices for composted dairy and pig manures. Soil Biology and Biochemistry 36: 767-776

Warren J G, Phillips S B, Mullins G L, Keahey D \& Penn C J (2006). Environmental and production consequences of using alum-amended poultry litter as a nutrient source for corn. Journal of Environmental Quality 35: 172-183 